\title{
TO GLOW WITH BRIGHT COLOURS: JIMMY GATZ'S TRIP TO OZ
}

\author{
DENNIS DUFFY \\ University of Toronto
}

\begin{abstract}
L. Frank Baum's The wonderful wizard of Oz (1900) could have furnished F. Scott Fitzgerald with a matrix of imagery and thematic for his The Great Gatsby (1925). The children's classic had sold widely and even been dramatized during Fitzgerald's childhood. Its emphasis on the greenness of the Emerald City foretells the role played by the colour green in Fitzgerald's novel. Baum's relentless optimism offers a foil to the profoundly tragic vision of the novelist; his title figure (also from the American Midwest) resembles Gatsby in his fraudulence. The shallowness of material fulfilment had preoccupied Fitzgerald since "The Diamond as Big as the Ritz" (1921). Gatsby enriched that vision. Could Wizard have furnished him with a network of imagery?
\end{abstract}

Denslow has made profuse illustrations for it and it will glow with bright colors.

(L. Frank Baum to Harry Baum, April 8, 1900.

In F.J Baum and Macfall 1961: 199)

But there was a change in Gatsby that was simply confounding. He literally glowed; without a word or a gesture of exultation a new well-being radiated from him and filled the little room.

( Fitzgerald 1991: 70).

America is surely not the only culture in which a passion for material things has been elevated to romance, but it is surely one of the few cultures to have so thoroughly examined this romance.

(Oates 1992: 582). 
What American classic is coloured green, features eyeglasses, balloon ascents, and roads, and has for a title figure a sham hero from the Midwest? Right you are, if you answer, The Wonderful Wizard of Oz! Right also, if you answer The Great Gatsby!

L. Frank Baum's Introduction to his best-known story emphasizes that his fantasy was a particularly modern, progressive, by implication American fairy tale, "a modernized fairy tale in which the wonderment and joy are retained and the heart-aches and nightmares are left out" (Baum 1973: 85). Imagine that, later, a writer undertakes a retrogressive American fairy tale, where life's voyage is engulfed in backward, pastward currents. Could the land of $\mathrm{Oz}$ present a ready-made version of that optimistic culture that the novel subverts? What if this tragedy rested upon a foundation of parody? What if it mocked a collection of motifs that an American audience was bound to recognize as representing progress and release, the "orgastic future" that lay before them, at the end of a yellow brick road? In His Steps, The Rise of the Colored Empires: actual and fictional texts dot The Great Gatsby, indicating the shallowness of a national culture. Why not include a text never named, but whose features appear below every pentimento? Her first visit to Oz's palace finds Dorothy browsing in the library there. Her attention is caught by a "row of little green books" (Baum 1973: 204). Could they be her story's literary offspring? Is The Great Gatsby one of them?

Both narratives concern themselves with inflation. The fraudulent Wizard fetches up in Oz after his hot-air balloon is blown astray, and departs from the Emerald City in the same vehicle. Fitzgerald's vapid, beguiling Midwestern heroines, Jordan and Daisy, first appear as aerial voyagers, "buoyed as though upon an anchored balloon." Then, at the end of the same paragraph, the narrator whisks out his sharp pin, and "the two young women ballooned slowly to the floor" (Fitzgerald 1991: 10).

Inflation/deflation,fantasy/realism,idealism/materialism: like some modern day Rape of the Lock, Gatsby plays parodically with a set of motifs that Fitzgerald's national culture employs as the grammar of fulfilment. The satirist blows up through deflation the balloon that he has already blown up to inflate.

A matrix, perhaps never deliberately sought, and certainly unacknowledged, for the imagery of that inflationary culture lay before Fitzgerald and his audience. Surrounded by desert, rectilinear, discoverable only by chance, the Land of Oz sits there as a shadow version of the American heartland. Baum styled himself its "Royal Historian." Fitzgerald could have served as its mordant, prescient Fool. Baum, when writing boys' adventure books, used the pen name of "Captain Hugh Fitzgerald." Lieutenant F. Scott Fitzgerald needed no such promotion (Brotman 1980: 162). 
Baum's fantasy first enjoyed a popular success and then became a cultural institution weighty enough to appear on a postage stamp. It embodies the American religion, the secular cult of self-actualization. As Ronald Baughman notes, the message is a simple one: "we get what we have" (Baughman 1955: 18; see also Nathanson 1991). From its first appearance, the tale and its illustrations fitted tightly into the American grain. For this reason one of the nation's finest illustrators employs an image from $\mathrm{Oz}$ when he draws a scene from a classic American tale, a gesture bearing a set of associations with the finale of Gatsby. This merits examination.

Groups of exotics appear at the end of Gatsby and the opening of Wizard: Dorothy Gale first encounters the Munchkins, while Nick Carraway leaves us with his imaginary Dutch sailors. Marius Bewley, finds the "pastoral world" of Oz reminiscent of the world the sailors found; the resemblance may run deeper (Bewley 1970: 277-67). Those Dutch sailors first sailed up the Hudson and into the canon of American imagery when Washington Irving introduced them to Father Knickerbocker. He then beached them in the Kaatskills with Rip Van Winkle, in a town built of "small yellow bricks." The Dutchmen Rip encountered at that first American bowling tournament were "odd-looking personages," whose "visages, too, were peculiar" (Washington Irving 1983: 775). Perhaps the first grotesques to appear in American fiction, Wyeth's revenant Dutchmen resemble Denslow's Munchkins ${ }^{1}$. Did these fantastic creatures also furnish Fitzgerald with his Dutch sailors?

Fitzgerald's novel provides a title-figure, and Baum's a set of supporting characters, who prove outstanding examples of self-made men. What are the translated Scarecrow, Tin Woodman, and Cowardly Lion but self-actualizing individuals springing from a "Platonic conception" of themselves (Fitzgerald 1991: 99)? The fraudulent Wizard's lesson: to envision courage, heart, or brain is to possess it. The secular, born-again Jimmy Gatz, the Gatsby whom some say "killed a man," or who sojourned at "Oggsford" with the Earl of Doncaster or won the Order of Danilo I from "little Montenegro by the sea," lives this belief. Like the Dorothy who first whirled to Oz and then heel-tapped back to Kansas, he understands in his very bones that, "[O]f course, you can"” repeat the past (Fitzgerald 1991: 111).

We lack any evidence that Fitzgerald pored over the endpapers that mapped Oz. In view, however, of the work's immediate popularity-ten thousand copies in the first two weeks; nearly 90 thousand by the end of 1901; 4, 195, 667 by the time copyright expired in 1956-Fitzgerald would have to have been the only middle-class child in mid-America to have missed out on this map exercise (Hermetz 1989: 294). The story framed by those bindings of The Wonderful Wizard of $\mathrm{Oz}$ could have furnished the novelist with a chart of

1. These figures can be viewed in Douglas Allen 1972: 107 and in Baum 1973: 101. 
the fantasy-tripping America that The Great Gatsby explores. Baum's story, like some high-bouncing lover, hovered over any American writer seeking to represent popular fantasy life, whether to endorse or subvert it. Setting, imagery and characterization alike display how thoroughly Fitzgerald mined the vein that Baum first opened, only to finally — in the manner of an earlier creation of his- blow up the mine itself.

Mining absorbs Fitzgerald's first excursion into pop fantasy. Excavation and demolition lie at the center of "The Diamond as Big as the Ritz," written in the winter of 1921-22. John T. Unger makes a summertime visit to his St. Midas School classmate Percy Washington's Wyoming estate, in part of that Far West where Baum located Oz (St-John 1982: 351-52). He finds it walled off within a valley ringed by a diamond mountain, the basis of the family's wealth. Defensive armaments and wholesale bribery of mapmakers ensure their seclusion. Black Americans, unaware that the days of slavery have ended, minister to the family. Falling in love with one of Percy's sisters, Kismine, Unger discovers that other suitors have been put to sleep rather than allowed to return to the world with news of the valley. A similar fate (Kismet?) awaits him. A number of airmen who have overflown the place are kept in prison there. The valley is destroyed when friends of the missing fliers come to bomb the place; patriarchal Braddock Washington gathers his family and retainers, retreats into the diamond mountain, and detonates it. John and Kismine witness the götterdammerung from the place whence they have fled.

Malcolm Cowley discerns within this story an earlier version of Gatsby. Certainly the appearance of the phrase, "platonic conception," alerts the reader to Gatsby's debt to "The Diamond" (Cowley, "Editor's Note" in Fitzgerald 1987: 3; "Platonic": Fitzgerald 1991: 77; "The Diamond as Big as the Ritz" in Fitzgerald 1987: 11). Significantly, "Diamond's" "platonic conception" becomes realized in the luxury of a prison cell. Fitzgerald seems to be bending Plato's concept, since the cell is merely an opulent, rather than an ontologically essential, version of prison-ness. Made of diamonds, it seems "beyond human wish or dream" (Fitzgerald 1987: 12). Gatsby's "Platonic conception of himself," on the other hand, is a heightening, a vision of the highest possibilities for selfhood. That is, it is something like a balloon ascension. Yet as we have already seen, what comes up, must come down.

"Diamond's" disillusioned hero, John, first discovers the alienation and oppression that supports the Washington family's magic kingdom. Shortly afterward, he and his heartthrob Kismine escape its fall, only to discover their mutual emotional distance. Kismine, so jaded with diamonds as to have fled with a pocketful of zircons, babbles about supporting them as a laundress. 
John predicts that their lifelong love will last a year, declares that youth is a form of "divine drunkenness," and that diamonds and disillusion seem to be what the world is made of. He himself can make only "the usual nothing of it," and falls asleep to escape consciousness for a few hours (Fitzgerald 1987: 37-38).

John T. Unger hungers for the dream of material enrichment--embodied in Kismine - that will give him lift- off from the Mississippi River town of Hades. Like another classic American traveller from a river town, John has seen behind the mask of "sivilization". Unlike Huck Finn, John has no territory that he can light out for. Back to Hades he must go, to a balder version of the Midwest than Gatsby narrator, Nick Carraway's, nostalgia-drenched "dark fields of the republic [that] rolled on under the night" (Fitzgerald 1991: 141).

As is often the case with fantasy narrative, details of the dystopia-the faery palace beside the diamond mountain, the imprisoned aviators, the enslaved blacks with their unintelligible patois-engage the reader's attention more than does the hero's psychological disposition. Yet, "Diamond" generates its narrative torque from the same forces that power Gatsby: the synergy formed by the simultaneity of wonder and ennui. In the later work, Fitzgerald discards fantasy as his source of wonder; the simple pleasures of the rich will instead lead his hero toward ruin.

A pattern has been set, however. "Diamond" relies upon the devices of fantasy to convey the enchantment to which his hero will succumb for a time. Fitzgerald parallels Baum in his use of fantasy, and both writers Americanize their enchanting material. These are not the gardens of Klingsor, but American spaces, literary forerunners of Henry Ford's Greenfield Village and Disney's Magic Kingdom, small-town America as fairyland. Its characters talk in American, rather than in formal English. Braddock Washington shows off his golf course; “'all a green, you see-no fairway, no rough, no hazards"” (Fitzgerald 1987: 20). The guardian of another sizeable green, the sentry at Oz's palace, bids his visitors, "Please make yourselves comfortable while I go to the door of the Throne Room and tell Oz you are here"' (Baum 1973: 203). Thus, the magical valley of "Diamond" has a road running through it, a particularly American one. Paved with "tapestry brick," an up-market, textured brick patented in Fitzgerald's time, the road surface here is no less emblematic of enchanted opulence than the yellow bricks of Baum's road ${ }^{2}$.

2. "Tapestry Brick's" manufacturers (Boston's Fiske and Company) described their product in terms appropriate to the Land of Oz: "It is impossible to describe or illustrate the color effects of this wonderful material. The delicate gradations of light and shade can be represented no more truthfully by printer's ink than can the living fire itself on the glowing hearth" [Tapestry Brick Fireplaces, a few examples 1911, 5.] My thanks to Nancy Porteous of the Metropolitan Toronto Reference Library for putting this trade catalogue before me. 
The Washingtons' palace, its "marble radiance half the height of an adjoining mountain," its "chiselled wonder of a thousand yellow windows," its "tallest" tower with "an arrangement of exterior lights" that "made a sort of floating fairyland" (Fitzgerald 1987, 11) recalls an Emerald City as big as the Ritz.

As they walked on, the green glow became brighter and brighter, and it seemed that at last they were nearing the end of their travels. Yet it was afternoon before they came to the great wall that surrounded the City. It was high, and thick, and of a bright green color (Baum 1973: 195).

Even as John Unger finds himself gazing up "in warm enchantment" (Fitzgerald 1987: 11) at the sound of violins that floats from the palace, a similar bedazzlement causes the Scarecrow to blink:

In front of them, and at the end of the road of yellow brick, was a big gate, all studded with emeralds that glittered so in the sun that even the painted eyes of the Scarecrow were dazzled by their brilliancy (Baum 1973: 195).

In his first configuration of the wondrously tawdry world that will later enchant his yearning hero, Fitzgerald relies upon a set of devices derived from the fantasy tradition that produced Baum's The Wonderful Wizard of Oz. In his own version of natural supernaturalism, Fitzgerald discards the fantasy rabbit. Yet he hangs on to the hat where he pulled it from. Colour imagery and characterization alike point to an Oz looming behind Gatsby's dazzling magnification.

Fitzgerald nearly chose a purely colourful title for The Great Gatsby: "Under the Red, White, and Blue." Gatsby uses the word "green" 17 times. Blue and yellow appear on 22 occasions. Gray, 17; silver, 11; gold, 18; red, 9; pink, 6 . The gaudy palette of Mannerist painting limns a scene whose ultimate meaning recalls the technique of Impressionism: all is evanescent in Gatsby, everyone in it caught up in a dance to the music of colour. Synaesthesia allows Fitzgerald to follow Bach in composing a chromatic fantasy and fugue. Colour melds with music to replicate the first part of Bach's title: "The moon had risen higher, and floating in the Sound was a triangle of silver scales, trembling a little to the stiff, tinny drip of the banjoes on the lawn" (Fitzgerald 1991: 39). The novel's concluding image — "boats against the current, borne back ceaselessly into the past" (Fitzgerald 1991: 141)— underlines its fugal qualities. Everyone in the novel has been there and back again; shifts in time and colour serve only to underline the passing nature of every supposedly enduring 
moment.

In the process of being and becoming, in those Prufrockian blue gardens where "men and women came and went like moths," wash upon wash shifts recolours the ground against which the figures strut. Gatsby's party guests are not the only objects in the novel that are "gaudy with primary colors" (Fitzgerald 1991: 33-34). Colour defines characters and their social station. Who does not recall Gatsby's pink suit and yellow "circus wagon" of a car and Tom's scorn for it? Colour, as in the passage about the tinny banjoes beside the silver Sound, defines a mood, a moment, at once enduring and ephemeral. Nick's swooning response to this epiphany - "the scene had changed before my eyes into something significant, elemental, and profound" (Fitzgerald 1991: 39) - may be suspect in its intensity. Two "finger-bowls of champagne" precede the illumination; the very fact of its occurrence however, underlines the importance of those "blue gardens," and "yellow bugs" that set the tone of Gatsby's parties (Fitzgerald 1991: 33). At those affairs, the host plays a mysterious, evasive, almost neutral role himself. He is the provider of colour rather than a colourful figure. His dress on their first meeting eludes comment, with Nick remarking only on his tanned skin and short hair (Fitzgerald 1991: 41).

Gatsby comes most vividly into his own, however, when he charges with brightness his first, awkward re-encounter with Daisy. Trapped in his white suit (the same colour that Daisy first wears), unable to speak except in stilted formalities, he flings about his wares with the abandon of an Indian silk merchant, performing a pied, kinetic self-definition:

While we admired [the shirts] he brought more and more and the soft rich heap mounted higher--shirts with stripes and scrolls and plaids in coral and apple green and lavender and faint orange with monograms of Indian blue.

Daisy thrills to the colour of Gatsby's statement, quickly fetishizing him into a rainbow-maker:

Suddenly with a strained sound Daisy bent her head into the shirts and began to cry stormily.

"They're such beautiful shirts," she sobbed, her voice muffled in the thick folds. "It makes me sad because I've never seen such--such beautiful shirts before". (Fitzgerald 1991: 72-73).

Pink suits, yellow cars, blue shirts, and above all, green lights, contrast with white and gray. The whites of Daisy and Jordan's dresses stand alongside the whiteness of Nick's fantasized, pastoral New York that situates itself finally in the moral squalor of Myrtle Wilson's white wedding-cake of an 
apartment, the whiteness of Meyer Wolfsheim's cuff-links made of teeth, the racial construction of Tom Buchanan's whiteness, stoutly resisting the threat posed by the "Rise of the Coloured Empires" (Fitzgerald 1991: 25; 57; 14). This is the whiteness of Ishmael's whale, the terrifying absence of meaning to which the obsessive Ahab ascribes significance.

Colours, then, shape the texture of Gatsby. Equally significant in Wizard, they are best observed by considering the role played by green and gray in both novels. The fictional creature, Jay Gatsby, glowed figuratively through the efforts of Fitzgerald's imagination. The glow that Frank Baum proudly pointed out to his brother was a literal one, the result of W.W. Denslow's illustrations and the new technology that could produce The Wonderful Wizard of Oz as a multi-coloured text. As William Leach points out in his definitive study, colour printing had a significance for Baum and his audience extending beyond any technological advance in the printing trade. Baum had not only worked as a designer and booster of retail window displays; he had theorized the subject, and produced the first magazine and a book on the subject. The Art of Decorating Dry Goods Windows and Interiors appeared the same year as the Wizard. A year earlier, as Michael Patrick Hearn points out, William M. Couran published "The Scientific Arrangement of Colors" in Baum's periodical, The Show Window. The map of $\mathrm{Oz}$ in fact follows the scheme put forward by Couran's theory (Hearn in Baum 1973: 114-15 n.5). Less theoretically, Denslow and Baum produced a volume whose bold appearance enthraled a reading audience already captured by the transformation that colour in advertising had already brought about in the marketplace. The author of the fabulously successful Frank Merriwell series, for example, attributed a portion of his series' successful debut in 1896 to its appearance within a colour cover. The new print technologies were enticing consumers to dream in colour, as it were. The development of national markets, the creation of the attitudes necessary to fuel a consumer economy, the supplanting of the work ethic by a hedonistic one: colour advertising embodied all those changes (Leach in Baum 1991: 3, 164-65; Patten 1964: 180). Advertising had made both familiar and welcome the appearance of colour in print. It was that new-found wonder that the Land of $\mathrm{Oz}$ conveyed. Self-actualization, we recall, is the message of Wizard, the message of the man with enough grit to push on until he rediscovers the inner strengths that have been there all along. Typographic and illustrated texts alike enshrine a message about American life that the endless replay of the canonized film version ritualizes. It is the message of the pleasure principle enthroned, but become a constitutional monarch. Dorothy triumphs in Oz, but eagerly returns home. Pleasure reigns, reality rules. Neither wars upon the other. Something is here for everyone, and Michael Lesy's Wisconsin Death Trip puts superbly that universal appeal: "They followed yellow brick roads to emerald cities presided over by imaginary 
wizards who would permit them to live in happy adolescence for the rest of their lives" (Lesy 1973, unpaginated).

Gatsby "paid a high price for living too long with a single dream". That struggle between dream and actuality - "what a grotesque thing a rose is and raw the sunlight was upon the newly created grass" (Fitzgerald 1991: 126) _ works itself out in the contrast between two colours, gray and green. The same colours underlie the spectrum of Wizard. Gray in Gatsby is the colour of the wraithlike George Wilson, who will later kill Gatsby in an act of misplaced, ultimately absurd vengeance. Chameleon-like, Wilson takes his coloration from the vast dump, the Valley of Ashes whose margins he dwells along. Green is the last colour flashing upon the reader's inward eye, the green of the light on Daisy's boat dock, the green thrilling the Dutch sailors upon their first sighting of Long Island. Shades of implication then link Gatsby's delusive dream of Daisy with the Euro-American construct of the wondrous New World. The Valley of Ashes, in the person of George Wilson, intrudes its grayness upon the verdant dream of Gatsby, an opposition that has driven the story from its beginning.

Baum's Wizard, we recall, made use of trick glasses to force others to envision his Emerald City. That delusional green that attracts both Gatsby and the Wizard, Baum first encountered during the 1893 depression that wiped him out as a dry-goods' storekeeper in North Dakota. Then he had heard tell of a desperate farmer who had put green goggles on a starving horse, hoping to convince him that a pile of wood shavings was in fact fodder (F.J. Baum 1961: 74). All the more reason for making Dorothy's "great Kansas prairies" the grayest place on earth. "Gray" appears four times in the fantasy's second paragraph, where it describes prairie, land, grass, and dwelling place (Baum 1973: 91-92). The green of the Emerald City conveys an almost orgasmic-or "orgastic," as Fitzgerald wrote it-release from this grayness of real life, and we have already noted the wonder that the first glimpse of it evokes ${ }^{3}$. Yetand here the resemblance to Gatsby extends beyond a use of colour and into a thematic of it-the city that beckons with the promise of surcease from the grinding dullness of rural life is based upon an illusion. The author of that fraud flim-flams his marks into mistaking the green world for its duller counterpart. In so doing, this figure of greatness recalls Fitzgerald's.

3. I use "orgasmic" deliberately. Everyone now knows of Edmund Wilson's alteration of Fitzgerald's sexually explicit neologism, "orgastic" to the milder "orgiastic" at the end of Gatsby ["Textual Notes" Fitzgerald 1991: 154.] Something similar may have happened in Wizard. Baum's Introduction uses the word "pleasure' as a transitive verb: "to pleasure children of today." The 1944 reprinting changed the word to "please." [Baum 1973: 85-86 n.6] Was this the result of a discovery that in colloquial Southern American speech, the verb "to pleasure," connotes delighting one's partner during sex? 
Both leading characters make spectacles of themselves, which explains why eyeglasses figure so prominently in both narratives. Those that the Wizard of $\mathrm{Oz}$ issues are tools of deception, forerunners of the gimmicky 3-D movie craze of the Fifties. Gatsby has his difficulties with vision, but they lie more in the figurative than in the organic line. When his oncoming death forces him to look up "at an unfamiliar sky through frightening leaves" and shiver as he finds out "what a grotesque thing a rose is and how raw the sunlight was," he is seeing things in a new light, rather than seeing them for the first time. Like the man born blind whom Jesus heals, Gatsby passes through stages of recovering vision, moving in the power of his perception from trees to men, as he finally beholds his killer "gliding toward him through the amorphous trees" (Mark: 8, 22-26; Fitzgerald 1991: 126).

The figure whose vision not even glasses can help is a disembodied one, Dr. T. J. Eckleburg. "Wild wag of an oculist" set out his billboard advertising his wares overlooking a giant dump. Generations of readers, encountering this enormous icon of sightless, extinct observance, of "eternal blindness" that "brood[s] on over the solemn dumping ground," have discerned here an emblem of a missing god. George Wilson does the same in the novel, but his friend, Michaelis, dismisses the figure as having no more significance than an advertisement (Fitzgerald 1991: 125). Wilson, we feel, seems the more alert reader. However we choose to read this version of a waste land, Fitzgerald's first figuration of it reminds us of Baum's monochrome Kansas. The gray scene first resembles "a fantastic farm where ashes grow like wheat into ridges and hills and grotesque gardens" (Fitzgerald 1991: 21; emphasis added).

$\mathrm{Oz}$ the Great and Terrible is a humbug; his green glasses glamorize the Emerald City. Eckleburg's painted lenses image what Wallace Stevens called, a short time before the publication of Gatsby, the "Nothing that is not there and the nothing that is" (Stevens 1972: 54). None of the eyeglasses really work: neither Eckleburg's nor the Wizard's nor the desperate Dakota farmer's. Their very function is to make us see, but not through any intrinsic power of their own. What they help us to "see," that is, to understand, is our willingness to ascribe visionary power and significance to things that are bogus. Fitzgerald's Nick Carraway provides us with another name for that willingness to discover visionary significance in objects incapable of generating it: "romantic readiness" (Fitzgerald 1991: 6). Examining the context in which that term occurs presents us with another set of affinities between Gatsby and the Wizard.

Both Oz himself and his subjects emphasize his ambivalent nature. "Is he a good man?"” Dorothy asks an old Munchkin woman. Her reply sidesteps the question: "He is a good Wizard. Whether he is a man or not I cannot tell, for 
I have never seen him"” (Baum 1973: 107). This precedes Oz's attempt at selfexculpation when Dorothy confronts him over his false promises:

'I think you are a very bad man,' said Dorothy.

'Oh, no, my dear; I'm really a very good man; but I'm a very bad Wizard, I must admit' (269). ${ }^{4}$

In the same way, Nick heavily qualifies his endorsement of Gatsby. The "Gatsby who represented everything for which I have an unaffected scorn" is invoked in the very paragraph praising his "romantic readiness." Gatsby, who "turned out all right in the end," nonetheless alienates Nick from his surroundings on account of the "foul dust [that] floated in the wake of [Gatsby's] dreams" (Fitzgerald 1991: 5-6). The Gatsby whom Nick declares "worth the whole damn bunch put together" is also the launderer of forged bonds, the friend of fixer Meyer Wolfsheim (Fitzgerald 1991: 120). The ambiguity of Gatsby permeates the novel, compelling readers to recognize also the doubleness of Nick Carraway. Nick, who so strongly identifies with Gatsby, is himself not a man of his word. He is Jordan Baker's "bad driver," playing a double game with the girl back home (Fitzgerald 1991: 138, 19, 48). Could Nick be a bad man but a good narrator, and Gatsby a good man but a bad dreamer? Is Carraway a self-deceiver whose rhapsodic opinions on Gatsby deserve no greater credence than Gatsby's versions of his own history? Gatsby pinpoints his middle-western origins in San Francisco (Fitzgerald 1991: 52)! Is Nick's statement that he is himself "one of the few honest people that I have ever known" as valueless morally as Gatsby's is geographically (Fitzgerald 1991: 48)? Is the novel a flawed but well-meaning narrator's tribute to a flawed but naively compelling hero? Or is it instead one adolescent, hero-worshipping liar's fantasy about another? Are we looking at self-examination or selfacquittal?

Assume that Gatsby's readers seek a definite moral evaluation for the meaning of events there. Does the text pose the sort of questions that can elicit straight answers? We are, for the most part, content to respond with admiring ambivalence to the choices of interpretation that Gatsby lays before us. This recognition in turn bears an odd relevance to the less complex, but still problematic meaning of The Wonderful Wizard of $\mathrm{Oz}$.

4. Baum enjoyed playing tricks. His frequent citation of spurious Biblical quotations disturbed his mother, and he expressed his delight at the possibilities for illusion that the film medium offered with the thought that "A camera can be made a fine liar." [Baum 1973: 72 n.31, 54.] Similarly, the author cannot make up his mind about the reputation of his trickster Wizard. Hearn points out that at first, Oz's former subjects "remembered him lovingly;" yet by the time of The Marvelous Land of $O z$ (1904), they have come to revile him [Baum 1973: 288 n.7]. 
The first of these problems, an inconsistency of outlook that is never resolved in the story, leads on to the second, which is that of a rewriting of the text that irons out the earlier inconsistency at the expense of imaginative power. The reader must take on faith Dorothy's burning wish to leave Oz and return to her gray, threadbare existence with Aunt Em. Dorothy never explains exactly why she is "so glad to be at home again!" (Baum 1973: 341). Assume that we find convincing Dorothy's rejoicing. Why? What can be attractive about the gray, hard-scrabble Kansas and the dour couple who parent her? Our own nostalgia about family life, some set of convictions that we bring to our reading, can alone ease us into accepting that ending. Nick's final threnody on his Midwest and the promise of those dark fields of the republic: does that replicate a similar illogic?

More to the point about our ambivalent response to the two texts is the question raised by the 1939 rewriting of The Wonderful Wizard of Oz, when the adjective was dropped from the title. The MGM film remains now the way in which most people experience the story. There the book's fantastic elements are eliminated by the dream framework. Dorothy in The Wizard of $\mathrm{Oz}$ awakes from the dream that she experienced after being knocked unconscious by the tornado to find in Miss Gulch, the farm hands, and the snake-oil salesman the real-life models for her fantastic companions in Oz. The final lines of the screenplay go beyond Baum's text in emphasizing the home-sweet-home theme; the fact that it has all been a dream indicates that Dorothy never really escaped from black-and-white Kansas into the colour of Oz. Rather than challenging the dulness of the unimagined life, the sojourn in Oz has only confirmed "reality's" essential wholesomeness, desirability, and comfort. As Douglas Street puts it, "an adventure fantasy for children has metamorphosed into a complex dream escape for adults" (Street 1984: 91-98). Strangely enough, this re-writing of Baum does not originate with the many writers who played their patchwork role in coming up with the final film script $^{5}$. The critical apparatus attached to a laser disk print of the film presents a clip from an animated cartoon version of the story. Produced in 1933, the 'toon foreshadows the 1939 film in stressing the hallucinatory, rather than the fantastic nature of Dorothy's time in Oz. Lacking the elaborateness of the framing device used in the film, the cartoon's simple, it's-all-a-dream device underlines just how seriously Hollywood took the task of imposing a "safe" interpretation upon Baum's text, one that affirms the pleasure principle's subordination to reality. Long before the Hollywood studio system at its peak

5. Harmetz's The Making of the Wizard of $\mathrm{Oz}$ reviews the making of the screenplay, though even her thoroughness fails to include all claimants (Harmetz 1989: 25-61). The lyricist E.Y. Harburg, for example, has asserted that he sneaked liberal sentiments into the script despite the watchfulness of studio executives [Francis MacDonnell 1990: 71-75]. 
decided to tame that text, its subversive implications had been recognized and rooted out (Esburgh 1933). Gatsby's ambiguities of characterization and narration, as we have seen, induce an ambivalent response to Fitzgerald's tale. The earlier and late movie rewritings of Wizard demonstrate how sensitive Hollywood was to Baum's imaginative message, and how diligently it sought to impose univocality upon a story that continues to attract variant critical readings. ${ }^{6}$

The Wonderful Wizard of $\mathrm{Oz}$ presents Fitzgerald with images and motifs that compose targets for his satiric questioning of that fantasy's message. Baum's instant classic offered the very stuff of the myth of self-creation and self-actualization that The Great Gatsby appears to scorn. I stress "appears," because the ambivalence of Nick's attitude toward Gatsby, as well as the unresolvable question of the extent of the author's agreement with his narrative persona, deny us any simple estimation of that novel's meaning. Perhaps the same is true of the celebration of the fantastic that lurks at the heart of The Wonderful Wizard of $\mathrm{Oz}$.

IV

Her first visit to Oz's palace finds Dorothy browsing in the library there. A "row of little green books" catches her attention. They are "full of queer green pictures that made her laugh" (Baum 1973: 204). Michael Patrick Hearn observes in a note on this passage that one of these texts could easily be the one in which Dorothy is presently appearing (204 n.8). Suppose that Baum has written Dorothy into her own book, and even proleptically into the series of Oz books that would follow, both from himself and from others. Perhaps even The Great Gatsby is one of those texts. The answer however, to that question of just how far that little green bookshelf stretches lies somewhere over the rainbow.

\footnotetext{
${ }^{6}$ Contemporary readings of Wizard oscillate between locating a Populist message there, to uncovering instead a self-actualization mentality that denies Populism's social radicalism: Littlefield 1964; Erisman 1968; Leach 1991: 1-34. I subscribe to the latter viewpoint.
} 


\section{REFERENCES}

Allen, Douglas and Allen, Douglas, Jr. 1972. N.C. Wyeth. The Collected Paintings, Illustrations and Murals. New York: Bonanza Books.

Baughman,Ronald. 1955. "L. Frank Baum and the 'Oz Books"' Columbia Library Columns 4 (May 1955): 18.

Baum, Frank Joslyn and MacFall, Russell P. 1961. To Please a Child. A Biography of L. Frank Baum Royal Historian of Oz. Chicago: Reilly \& Lee.

Baum, L. Frank. 1973. The Annotated Wizard of Oz. The Wonderful Wizard of Oz By L. Frank Baum. Pictures by W.W. Denslow. With an Introduction, Notes, and Bibliography by Michael Patrick Hearn. New York: Clarkson N. Potter.

Bewley, Marius. 1970. "The Land of Oz: America's Great Good Place." Masks and Mirrors. Essays in Criticism. New York: Athaneum. 26667.

Brotman, Jordan. 1980. "A Late Wanderer in Oz". Only Connect: Readings in Children's Literature. Eds. Sheila Egoff, G.T. Stubbs, and L.F. Ashley eds. 2nd ed. Toronto: Oxford University Press. 156-69.

Bruccoli, Matthew J. 1974. APPARATUS for F. Scott Fitzgerald's "The Great Gatsby [UNDER THE RED, WHITE, AND BLUE]. Columbia, SC: University of South Carolina Press.

Crosland, Andrew T. 1975. A Concordance to F. Scott Fitzgerald's "The Great Gatsby". Detroit: Gale Research.

Erisman, Fred. 1968. "L. Frank Baum and the Progressive Dilemma," American Quarterly 20 (Fall 1968): 616-23.

Esburgh, Tod. 1933. The Wizard of Oz. Cartoon. The Wonderful Wizard of Oz. The Making of a Movie Classic. ML 104756, The Ultimate Oz. MGUA Home Video ML104755.

Fitzgerald, F. Scott. 1987. The Stories of F. Scott Fitzgerald. With an Introduction and Notes by Malcolm Cowley. New York: Scribners Macmillan.

Fitzgerald, F. Scott. 1991. The Great Gatsby, Ed. Matthew J. Bruccoli. The Cambridge Edition of the Works of F. Scott Fitzgerald. Cambridge: Cambridge University Press.

Hermetz, Aljean. 1989. The Making of the "Wizard of Oz". N.Y.: Delta Books.

Irving, Washington. 1983. "Rip Van Winkle". The Sketch Book of Geoffrey Crayon, Gent. History, Tales and Sketches. New York: Library of America. 767-85.

Leach, William R. 1991. "The Clown from Syracuse: The Life and Times of L. Frank Baum" and "A Trickster's Tale: L. Frank Baum's The 
Wonderful Wizard of Oz". L. Frank Baum, The Wonderful Wizard of Oz. Ed. William R. Leach. Belmont, CA: Wadsworth Publishing Co. 134; 157-88.

Lesy, Michael. 1973. "Conclusion". Wisconsin Death Trip. New York: Pantheon Books. Unpaginated.

Henry M. Littlefield. 1964. "The Wizard of Oz: Parable on Populism" American Quarterly 16 (Spring 1964): 47-58.

Long, Robert Emmet. 1979. The Achieving of "The Great Gatsby". F. Scott Fitzgerald, 1920-25. Lewisburg, PA: Bucknell University Press.

MacDonnell, Francis. 1990. "The Emerald City was the New Deal': E.Y.

Harburg and The Wonderful Wizard of Oz" Journal of American Culture 13 (Winter 1990): 71-75.

Nathanson, Paul. 1991. Over the Rainbow. "The Wizard of Oz" as a Secular Myth of America. State University of New York Press.

Oates, Joyce Carol. 1992. "Raymond Carver". The Oxford Book of American Short Stories, Ed. Joyce Carol Oates. N.Y.: Oxford University Press.

Patten, Gilbert. 1964. Frank Merriwell's "Father". An Autobiography by Gilbert Patten ("Burt L. Standish"). Ed. Harriet Hinsdale. Norman: University of Oklahoma Press.

St.-John, Tom. 1982. "Lyman Frank Baum: Looking Back to the Promised Land". Western Humanities Review. 36 (Winter 1982): 351-52.

Stevens, Wallace. 1972. "The Snow Man". The Palm at the End of the Mind. Selected Poems and a Play. Ed. Holly Stevens. New York: Vintage Books. 54.

— . 1911. Tapestry Brick Fireplaces, a Few Examples. (3rd. edition). Boston: Fiske and Company.

Street, Douglas. 1984. "The Wonderful Wiz That Was: The Curious Transformation of The Wizard of Oz". Kansas Quarterly 16 (Summer 1984): 91-98. 